\title{
A RELATIVIZAÇÃO DA RESPONSABILIDADE DO AGENTE NO CRIME DE ESTUPRO: NO ÂMBITO DA DOSIMETRIA DA PENA
}

\author{
Thissiane ChicarelL* \\ Professor Bruno Ap. Souza**
}

\section{RESUMO}

O objetivo do artigo é o estudo do tipo penal de estupro, comparando-o com os outros tipos penais existentes no Código Penal, especificamente, previstos no Título VI - Dos Crimes Contra a Dignidade Sexual, do Capitulo I - Dos Crimes Contra a Liberdade Sexual, e demonstrar como a chamada "cultura do estupro" influencia para que muitas vezes banalize- se o referido crime, o que resulta em condenações injustas que violam vários princípios constitucionais, como o princípio da presunção da inocência e o princípio da proporcionalidade, trazendo diversas consequências para a vida do acusado. Assim, realiza pesquisa descritiva e explicativa, a partir do exame de fontes bibligráficas (doutrina e jurisprudência), bem como, casos práticos, adotando-se o método de hipotético-dedutivo. Ao final concluiu que o crime de estupro é perfeitamente distinguível dos outros tipos penais existentes em nosso ordenamento jurídico e que é necessário que o julgador conheça seus elementos caracterizadores para que tais condenações injustas sejam evitadas e, principalmente, livres de ideologias.

Palavras-chave: Estupro. Cultura do estupro. Presunção da inocência. Princípio da Proporcionalidade.

\section{RELATIVIZING THE AGENT'S RESPONSABILITY IN THE RAPE CRIME: WITHIN THE SCOPE OF THE PENALTY DOSIMETRY}

\section{ABSTRACT}

The objective of the article is to study the criminal type of rape, comparing it with the other criminal types existing in the Penal Code, specifically, provided for in Title VI - Crimes Against Sexual Dignity, of Chapter I - Crimes Against Sexual Freedom and demonstrate how the so-called "culture of rape" influences so that it is often trivialized, which results in unjust convictions that violate several constitutional principles, such as the principle of presumption of innocence and the principle of proportionality, bringing several consequences for the life of the accused. Thus, it carries out descriptive and explanatory research, from the examination of bibligraphic sources (doctrine

* Bacharelada em Direito pela Universidade Metodista de São Pualo, e-mail para contato: cthissiane@yahoo.com.br

** Advogado. Professor, de Direito Penal e Processo Penal da Universidade Metodista de São Paulo. Pós - graduado em Direito Penal e Direito Processual Penal pela Faculdade Damásio de Jesus. Mestrando em Direito da Saúde, pela Universidade Santa Cecília 
and jurisprudence), as well as practical cases, adopting the hypothetical-deductive method. In the end he concluded that the crime of rape is perfectly distinguishable from the other criminal types existing in our legal system and that it is necessary for the judge to know its characterizing elements so that such unjust convictions are avoided and, especially, free of ideologies.

Keywords: Rape. Rape Culture. Presumption of innocence. Principle of Proportionality.

\section{INTRODUÇÃO}

O presente trabalho visa demonstrar que, após a minuciosa análise dos elementos que compõem o tipo penal descrito no art. 213 do Código Penal, quais sejam, coação, violência e grave ameaça para a prática de relação sexual ou ato libidinoso, possibilita-se a relativização da responsabilidade do agente quando do cometimento deste crime. Isto, em detrimento da denominada "culpa compensatória", levando-se em consideração, especificamente, o comportamento da vítima como circunstância judicial (art. 59, CP) com incidência na terceira-fase da dosimetria da pena, por meio da redução, em até 2/3 (dois terços), inclusive, da pena base prevista para ele, sob a observância das circunstâncias em que foi cometido.

Para isso, contextualizaremos doutrinariamente, sob a ótica, inclusive, da jurisprudência, o tipo penal descrito no art. 213, do Código Penal, desde a sua concepção ao seu momento consumativo, factualmente, no sentido de verificar quais atos efetivamente caracterizam o crime de estupro e, a contrário sensu, quais, sob nossa concepção, deveriam ser circunstancialmente relevantes levando-se em consideração determinadas conjunturas; além disso, em detrimento das recentes mudanças implementadas pela Lei 13.718 de 24 de setembro de 2018 no Código de Processo Penal, imprescindível se fará um estudo sobre o tipo penal descrito no art. 215-A, bem como, dos outros tipos penais que dizem respeito aos crimes sexuais.

Isto pois, atualmente, a chamada "cultura do estupro" - termo este utilizado para apontar comportamentos compreendidos sutis ou explícitos que relativizam a violência sexual contra a mulher, manifestada por meio do assédio, desrespeito e objetificação em razão do gênero - permite a equivocada, senão, intensiva, atribuição de qualquer conduta compreendida como violadora, a responsabilização pelo estupro.

Desta forma, a incompreensão, ou seja, a ignorância quanto à existência ou correta interpretação dos elementos caracterizadores do referido tipo penal, antecede (possíveis) condenações equivocadas, que por sua vez, evidenciam a clara violação a alguns princípios constitucionais, como por exemplo, o da presunção da inocência e consequentemente do in dúbio pro reo, pois, atualmente, a valorização primária da palavra da vítima prevalece como fundamento condenatório e, consequentemente possibilita julgamentos antecipados, por assim dizer, da culpabilidade do agente.

Obviamente, sem qualquer resquício de dubiedade, é absolutamente inviável a não existência de punição para o crime de estupro, acrescente-se, aliás, para qualquer crime contra a liberdade sexual, independentemente de gênero, contu- 
do, deve-se em minuciosa análise às circunstâncias do caso concreto, especialmente em contraponto à chamada "cultura do estupro", amplamente difundida nos dias atuais, permitindo, data vênia, vultosos exageros - intrínsecos no seio social - oportunizando condenações equivocadas (injustas), ocasionando seríssimas consequências para o acusado, inclusive, dentro do Sistema Carcerário, perpetuando a violação de diversos princípios constitucionais, máxime, da presunção de inocência, delimitar a efetiva caracterização desse tipo penal (incriminador).

\section{ESTUPRO X CRIMES CONTRA DIGNIDADE SEXUAL}

Nesta seção analisa-se as mudanças instituídas pela Lei 13.718 de 24 de setembro de 2018, bem como, os crimes sexuais descritos no capítulo VI Título I do Código Penal.

É sabido que atualmente o número de casos de estupro no país aumentou consideravelmente, causando grande balbúrdia, principalmente entre as mulheres, maiores vítimas desse crime. De acordo com Cerqueira e Coelho (2014, p. 6) estima - se que "a cada ano, no mínimo 527 mil pessoas são estupradas no Brasil. Desses casos, apenas $10 \%$ chegam ao conhecimento da polícia".

Consoante o $13^{\circ}$ Anuário Brasileiro de Segurança Pública (2019, p. 117), entre 2017 e 2018 houve 127.585 ocorrências de estupro e estupro de vulnerável, sendo que o ano de 2018 bateu recorde no número de registros, totalizando 66.041 casos.

Como resultado deste acontecimento temos o crescimento dos aficionados pela chamada "cultura do estupro", que conforme já explicamos, permite uma atribuição equivocada de qualquer conduta como crime de estupro.

Ocorre que, tal atribuição é, por diversas vezes, imprecisa. Isto porque, muitos desses atos cometidos contra as mulheres se enquadram em outro tipo penal que, diverso do crime de estupro, por sua vez acabam gerando condenações equivocadas que violam princípios constitucionais, como, por exemplo, o da presunção da inocência e consequentemente o do in dúbio pro reo.

É nesse cenário, portanto, que se fez necessária a alteração (processual) implementada pela Lei $\mathrm{n}^{\circ}$ 13.718, de 24 de setembro de 2018 no Código Penal, bem como, a criação do tipo penal previsto no art. $215 \mathrm{~A}$, também proveniente da predita Lei.

Ocorre que, as alterações efetivadas pela referida Lei, lamentavelmente, se demonstram ineficientes, senão, insuficientes, pois, a incondicionalidade da Ação Penal Pública nos crimes contra a liberdade sexual menospreza, incompreensivelmente, a capacidade de decisão da vítima. No mesmo sentido, o crime de importunação sexual (art. 215A, CP) demonstra-se ignoto e, consequentemente os variados atos compreendidos como violação continuam sendo equivocadamente interpretados como estupro.

Anteriormente a denominação do Título IV do Código Penal, "Crimes contra os costumes", segundo Greco (2017, p. 1120), idealizava a concepção de proteção sobre o como as pessoas deveriam se comportar, porém, esta concepção ficou ultrapassada, sobretudo em razão das modificações ocorridas na sociedade.

Nessa conjuntura tornou-se necessária a alteração trazida pela Lei 12.015, de 07 de agosto de 2009, renomeando o referido título para "Crimes contra a dignidade sexual", bem como, transmudando os tipos por ele abrangidos. 
Destarte, esclarecido o objetivo significativo da instituição da Lei 12.015/2009, abrangendo, substancialmente, a dignidade da pessoa humana nos crimes sexuais, notável se faz o estudo sobre os tipos penais concebidos neste título, máxime, do crime de estupro, abrangendo as alterações (penais e processuais penais) implementadas pela Lei 13.718/2018 e, igualmente, imprimindo nosso entendimento, sobre o que, exatamente, deveria prevalecer.

$\mathrm{O}$ art. 213 do Código Penal (Decreto-Lei $\mathrm{n}^{\circ}$ 2.848/1940), alterado pela Lei 12.015/2009 dispõe sobre a definição de estupro: “Constranger alguém, mediante violência ou grave ameaça, a ter conjunção carnal ou a praticar ou permitir que com ele se pratique outro ato libidinoso..." (BRASIL, Código Penal, 2009).

Denota-se que com a leitura do referido artigo o conceito do crime de estupro é imperioso, não deixando margens para que haja inúmeras interpretações, assim:

[...] o delito abrange não só o fato de o autor constranger sua vítima a prática de ato libidinoso (com efetiva participação do ofendido), como também a situação em que faz com que aquela permita que com ela seja praticado tal ato (existe uma atitude passiva do ofendido). (SANCHES, 2017, p. 484).

Na definição de Gueiros e Japiassú (2018, p. 820), “cuida-se de delito classificado como hediondo e que atinge bens jurídicos diversos, tais como a dignidade e liberdade sexual, integridade física e psíquica, a honra, a saúde individual e, nos casos mais graves, a própria vida da vítima".

Desta maneira, a Lei 13.718, de 24 de setembro de 2018, cuidou de alterar única e exclusivamente sua natureza penal, ou seja, a matéria de cunho procedimental.

Art. 225 do Código Penal (Decreto-Lei $n^{\circ}$ 2.848/1940), alterado pela Lei 12.015/2009 e posteriormente pela Lei 13.718/2018, disciplina, in verbis: "Nos crimes definidos nos Capítulos I e II deste Título, procede-se mediante ação penal pública incondicionada". (BRASIL, Código Penal, 2018).

Nas palavras de Cebrian e Gonçalves (2017, p. 90), ação penal pública significa que "... o exercício do direito de ação pelo Ministério Público não depende de qualquer condição especial".

Ou seja, agora, os crimes contra a liberdade sexual não dependem de representação do ofendido, sendo a Ação Penal proposta diretamente pelo Ministério Público, levando-se em consideração unicamente os indícios de autoria e materialidade do crime.

Contudo, não nos esqueçamos, a referida Lei constituiu, também, o crime de 'importunação sexual', senão vejamos:

Art. 215 A. “Ter conjunção carnal ou praticar outro ato libidinoso com alguém, mediante fraude ou outro meio que impeça ou dificulte a livre manifestação de vontade da vítima: Pena - reclusão, de 2 a 6 anos". (BRASIL, Código Penal, 2018).

Destarte, pela referida inovação e consequente desinformação a respeito do tipo penal acima mencionado, possibilita-se a confusão entre os dois crimes, prevalecendo-se o estupro (analogia in malam partem). 
No que diz respeito ao crime de estupro, segundo Nucci:

O estupro já teve várias significações ao longo do tempo, consistindo, na essência, em violação sexual violenta, vale dizer, constranger pessoa à prática de qualquer ato libidinoso, inclusive a conjunção carnal, mediante o emprego de violência ou grave ameaça. (NUCCI, 2014, p.33).

Entende-se, da contextualização deste crime, que o mesmo se dá em detrimento da influência de todos os elementos (dele) caracterizadores, quais sejam, o constrangimento, violência ou grave ameaça para a prática de conjunção carnal ou ato libidinoso ${ }^{1}$.

Nessa senda, Marcão e Gentil (2018, p. 27) lecionam: “Objeto do crime é o próprio corpo da vítima, o qual, a seu contragosto, é empregado para satisfazer a libido de outrem, mediante violência física ou moral".

Assim o crime de estupro consiste basicamente em o agente obrigar a vítima a praticar ou deixar que com ela se pratique a conjunção carnal ou outro ato libidinoso.

Quanto ao crime de importunação sexual, este, de acordo com Bittencourt $(2018,1)$, tipifica condutas anteriormente obscuras em detrimento da lacuna, agora preenchida, existentes no Código Penal, como por exemplo, quando o agente ejacula na vítima no transporte público, nesse sentido:

Em situações como essas - agora tipificadas como importunação sexual - o executor da ação degradante violenta a dignidade sexual da vítima, que é ultrajada, vilipendiada e humilhada por uma conduta repugnante e indigna do referido agressor. Nessas hipóteses, a vítima ofendida fica impotente sem qualquer possibilidade de reagir ou se defender pelo inesperado, pelo inusitado, pela surpresa da "agressão" sexual realizada pelo agente, para satisfazer a sua lascívia ou a de outrem. (BITENCOURT, 2018, 1).

Deste modo, referido crime importa na conduta do agente de violar a dignidade sexual da vítima com alguma conduta repugnante; nessas situações a vítima fica impotente, sem possibilidade de reação ou de se defender pelo inesperado ato do agente de satisfazer a própria lascívia ou de outrem.

Importa mencionar que a conjunção carnal e ato libidinoso diverso (sexo oral e anal) estão excluídos desta infração penal, pois pela sua gravidade são desproporcionais à pena aqui cominada, sendo condutas tipificadoras do estupro.

Conforme já mencionado, com o crescente número de pessoas aficionadas pela cultura do estupro confunde-se constantemente os crimes contra a dignidade sexual, dessa forma, é bastante comum ver as pessoas intitulando algumas condu-

1 Salim e Azevedo (2017, p. 464) exemplificam alguns desses atos como "coito anal, manipulação de órgãos sexuais, masturbação, etc.". Ainda, Nucci (2019, p. 111), cita como exemplo de ato libidinoso "[...] introdução na vagina dos dedos ou outros objetos". 
tas como assédio sexual ${ }^{2}$, seja por desconhecimento do seu conceito ou por ainda não conseguirem assimilar o, novo, crime de importunação sexual. Mas este crime tem uma particularidade, senão vejamos:

Art. 216 A do Código Penal (Decreto-Lei n².848/1940), incluído pela Lei 10.224, de 15 de maio de 2001, dispõe: "Constranger alguém com o intuito de obter vantagem ou favorecimento sexual, prevalecendo-se o agente da sua condição de superior hierárquico ou ascendência inerentes ao exercício de emprego, cargo ou função". (BRASIL, Código Penal, 2001).

Nas palavras de Jesus Damásio:

Envolve, portanto, relação de poder, sujeição da vítima, ofensa à sua dignidade e, por fim, afetação à sua liberdade sexual. Tratando-se de assédio laboral, pode-se incluir outro bem jurídico importante: direito à não discriminação no trabalho (DAMASIO, 2013, p.143).

Ou seja, o crime de assédio sexual, além de ser um crime contra a liberdade e dignidade sexual, também protege a pessoa para que esta não seja importunada em seu local e trabalho ${ }^{3}$. Assim, não se deve atribuir a atos atentatórios contra a dignidade sexual fora do ambiente de trabalho, ou seja, correlato à hierarquia funcional, ascendência inerentes a exercício de emprego, cargo ou função, de trabalho a tipificação de assédio sexual devendo tais atos serem enquadrados como importunação sexual.

$\mathrm{O}$ art. 215 do Código Penal (Decreto-Lei n².848/1940), alterado pela Lei 12.015/2009 dispõe sobre a definição de violação sexual mediante fraude: “Ter conjunção carnal ou praticar outro ato libidinoso com alguém, mediante fraude ou outro meio que impeça ou dificulte a livre manifestação de vontade da vítima...". (BRASIL, Código Penal, 2009).

Já de início com leitura do tipo penal em comento, é possível identificar que o seu principal elemento caracterizador é a fraude, ou outro meio que dificulte ou impeça a livre manifestação de vontade da vítima ${ }^{4}$.

Sobre a caracterização desse elemento, temos o seguinte entendimento do Tribunal de Justiça do Estado do Rio Grande do Sul:

APELAÇÃO CRIMINAL. CRIMES CONTRA OS COSTUMES. ARTIGO 215 DO CP. VILAÇÃO SEXUAL MEDIANTE FRAUDE. SENTENÇA

2 Como, por exemplo, assobiar, ou tecer comentários constrangedores para a vítima.

3 Segundo Jesus Damásio (2013, p. 146), estaremos diante do crime de assédio quando, por exemplo, "uma eventual promoção ou mesmo aceitação no emprego encontra-se condicionada não a desempenho, capacidade ou dedicação no trabalho, mas a eventual aceitação de proposta de cunho sexual".

4 São exemplos, segundo Estefam: a) curandeiro que convence o cliente da necessidade de despi-lo e tocá- lo para expurgar seus males; b) o irmão gêmeo que se faz passar pelo outro para manter relação sexual com sua cunhada; c) o enfermeiro que, objetivando abusar de um doente (homem ou mulher), submete-o a atos de libidinagem a pretexto de aplicar-lhe injeção de que necessitava; d) o agente que, para ministrar aula de ginecologia a uma mulher, com ela pratica atos libidinosos. (ESTEFAM, 2018, p. 654). 
REFORMADA. ABSOLVIÇÃO DO RÉU. INEXISTÊNCIA DE FRAUDE. Réu que oferece carona a vítima e, durante o trajeto até a residência desta, pega na sua mão, passa a mão nas pernas da mesma, tenta beijá-la e propõe relacionamento. Fraude não caracterizada. A fraude exigida pela lei penal não se resume ao simples abuso de confiança ou ao mero prevalecimento da relação de parentesco existente entre o réu a vítima. Para estar caracterizada a fraude deveria o réu ter usado de subterfúgio capaz de convencer a vítima à prática dos atos que pretendia, o que não se verifica. Sentença reformada. Réu absolvido. APELO PROVIDO (Apelação Crime, N ${ }^{\circ}$ 70041208786, Sexta Câmara Criminal, Tribunal de Justiça do RS, Relator: Cláudio Baldino Maciel, Julgado em: 30-06-2011).

Isto é, conforme o referido entendimento, a fraude deve ser capaz de ludibriar a vítima, aproveitando-se o agente da confiança da vítima para satisfazer seus desejos ou necessidades sexuais, caso assim não seja, estaremos diante da atipicidade da conduta.

Ou seja, sem tal elemento caracterizador, e somente por meio dele o impedimento da livre manifestação da vontade da vítima, não estaríamos mais diante do crime de violação sexual mediante fraude, e sim do crime de estupro.

Conforme já vimos, todos os crimes contidos no Capítulo I, Título VI - Dos crimes Contra a Dignidade Sexual, objetivam proteger e tutelar a dignidade sexual.

Portanto, o exaurimento do crime se dará com a superação de qualquer das condutas que, interfiram na liberdade sexual da vítima, fazendo com esta seja obrigada a praticar ou deixar que com ela se pratique algum ato sexual contra a sua vontade.

Assim, o crime de estupro restará caracterizado quando na conduta houver a violência ou grave ameaça, enquanto o crime de violação sexual mediante fraude quando da existência da fraude para que a vítima ceda aos desígnios sexuais do agente.

Quanto ao crime de assédio sexual, este se dá quando há relação de subordinação entre patrão e empregado.

E por fim, mas não menos importante, estaremos diante do crime de importunação sexual quando o agente se utiliza de um momento de distração da vítima para atingir seu objetivo, qual seja, a sua satisfação sexual.

É possível concluir, portanto, que a principal diferença entre eles está no modo de execução, extremando-se que para o correto julgamento do caso concreto deve o julgador cingir-se das circunstâncias fáticas para que não haja condenações equivocadas. Destaque-se, aqui, além da análise de todas as demais circunstâncias judiciais dispostas no art. 59 do Código Penal, o comportamento da vítima como fundamental.

\section{CULTURA DO ESTUPRO E VITIMOLOGIA}

Nesta seção iremos analisar efetivamente os conceitos de cultura do estupro e como ela influencia para que muitos atos considerados violadores sejam caracterizados como estupro, 
bem como, o conceito de vitimologia para compreendermos a circunstância judicial de comportamento da vítima.

A chamada cultura do estupro é um assunto de grande repercussão social, isto porque, comumente, justifica-se por intermédio dela o grande aumento no número de casos de estupro, fundamentando-se na suposta existência de condutas que "facilitam" a ocorrência deste crime dessa forma. Tal cultura se refere à normalização da violência sexual contra a mulher na sociedade e na mídia, sendo resultado do comportamento da sociedade e a forma como se vive.

De acordo com Buchwald (2016, p.8) apud Guia Mundo em Foco: cultura do estupro,

A cultura do estupro é um complexo conjunto de crenças que incentivam a agressão sexual masculina e apoia a violência contra as mulheres. Esse fenômeno tolera o terrorismo físico e emocional contra a mulher. Sendo assim, homens e mulheres assumem que a violência sexual é um fato da vida, logo inevitável. Essa crença está presente em piadas, programas de TV, músicas, publicidades, leis, palavras e imagens que fazem com que a violência contra a mulher seja algo banal. A sociedade deixa assim de acreditar que é um problema grave que precisa mudar e crê que as coisas são como são, agindo de forma passiva diante de uma situação como essa.

Dessa forma, de acordo com o conceito dessa cultura, as mulheres são vistas pela sociedade como objetos sexuais que estão sempre à disposição dos homens, o que os leva a supostamente terem comportamentos que ensejam o crime de estupro, sendo que, de acordo com o Guia Mundo em foco: cultura do estupro (2016, p. 7), essa concepção está enraizada no ser humano desde os primórdios da humanidade.

Apesar disso, de acordo com o Guia Mundo em Foco: cultura do estupro (2016, p. 10), esse fenômeno passou a ganhar notoriedade apenas em 1970, na segunda onda feminista, quando passou-se a criticar tudo aquilo que na concepção deste grupo incitava o machismo.

Repise-se, o objetivo do presente estudo não é justificar a prática dos crimes sexuais, contrariamente, o objetivo principal é fazer uma crítica a este movimento que erroneamente influenciou os seus seguidores, fazendo com que atribuam ao estupro todo e qualquer ato que se correlacione e/ou viole a dignidade e liberdade sexual da mulher, justamente usando a justificativa de que a mulher é e sempre será vítima desse suposto machismo.

Se assim o fosse, estaríamos violando os mais diversos princípios e garantias constitucionais, tais como, dignidade da pessoa humana, presunção de inocência, entre outros, pois, apesar do inequívoco alto grau de reprovabilidade dos crimes contra a dignidade sexual, necessário se faz a devida tipificação, como consequência de uma construção normativa lógica.

O reflexo disso é que de forma geral, não há diferença entre o ato de passar a mão nas partes intimas da vítima e forçá-la por meio da violência e grave ameaça, a ter relação sexual ou deixar que com ela se pratique outro ato libidinoso. 
Isto não significa que o denominado machismo não é incidente no âmbito social feminino ou que por incontáveis vezes mulheres são rebaixadas ou menosprezadas. Contrariamente, a crítica é que não se deve fazer com que isso ultrapasse os limites do aceitável. Ainda, porque, em diversos casos mulheres se utilizaram de disposições normativas acerca dos crimes contra a dignidade sexual em benefício próprio ${ }^{5}$.

Conclui-se, portanto, que quando a cultura do estupro se sobrepões às disposições normativas, colide frontalmente com princípios e garantias fundamentais, materializando levar a condenações equivocadas. É, neste contexto que a análise jurisdicional deve se pautar, levando-se em consideração as circunstâncias que permeiam o crime, sejam jurisdicionais e/ou sociais, assomando a importância do comportamento da vítima.

Nos termos do artigo 59, do Código Penal (Decreto-Lei n².848/1940), constata-se que:

O juiz, atendendo à culpabilidade, aos antecedentes, à conduta social, à personalidade do agente, aos motivos, às circunstâncias e consequências do crime, bem como ao comportamento da vítima, estabelecerá, conforme seja necessário e suficiente para reprovação e prevenção do crime. (BRASIL, Código Penal, 1942).

Para melhor compreendermos o conceito de "comportamento da vítima", circunstância judicial central do presente trabalho, deveremos adentrar ao campo da criminologia e mais profundamente no campo da vitimologia. Basicamente a vitimologia é a ciência que se ocupa de estudar as vítimas dos delitos:

Vitimologia é um ramo da criminologia que teve início no final da primeira metade do século XX (termo usado pela primeira vez, por Werthan, na obra The show of violence 1974), que centra o seu estudo e suas atenções no comportamento da vítima, nos desdobramentos de sua conduta, em face do criminoso. A bem ver, não existe crime sem vítima, sendo inevitável a relação criminoso/vitima - vitima/criminoso, ou seja, uma via de mão dupla. (PALOMBA, 2016, p.173).

Conforme Penteado (2019, p. 99), dentro do campo da vitimologia existe a chamada classificação das vítimas, atribuída por Benjamim Mendelson, que leva em conta a participação ou provocação da vítima. Sendo assim, a classificação que nos interessa é a classificação em que a vítima é considerada tão culpada, mais culpada ou como única culpada pelo delito.

Nas palavras de Penteado (2019, p. 99), "é muito importante aferir o binômio criminoso/vítima, sobretudo quando esta interage no fato típico, de forma que a

5 Podemos citar, por exemplo, o caso do jogador Neymar, que foi acusado de estupro pela modelo Najila, extremamente enaltecida na mídia com o apoio de várias mulheres que são aficionadas pela cultura do estupro, e após investigações pela polícia descobriram que a modelo na verdade queria se aproveitar da condição financeira do jogador e acabou sendo processada por fraude processual, denúncia caluniosa e extorsão, segundo fontes do G1. (2019). 
análise de seu perfil psicológico desponta como fator a ser considerado no desate judicial do delito $[. . .]^{\prime \prime}$.

É claro que existem muitas pessoas, vítimas ideais, que não contribuem para que o delito ocorra, por isso, especialmente no âmbito dos crimes sexuais, é importante a análise do caso concreto; assim o papel da vitimologia nesses delitos é de extrema relevância.

Isto pois, conforme Paloma:

[...] a mulher, muitas vezes inconscientemente, se insere num ritual de conquista ao sexo oposto, com finalidade não reprodutiva, e no desenvolvimento e na aplicação deste processo apresenta conduta típica, não passiva, mas ativa, estimuladora, que pode desencadear no iminente delinquente uma expectativa de comportamento favorável a desígnios que já tinha ou que foram suscitados pela conduta da mulher. (PALOMBA, 2016, p.176).

Isso quer dizer que a mulher é culpada por ter sido vítima de um crime sexual? Não! Quer dizer que assim como existem mulheres que são totalmente inocentes, existem mulheres que provocam o crime, seja por motivos egoísticos ou por certa ingenuidade, por acreditar, por exemplo, que um estuprador é machista ao invés de cometer crimes sexuais simplesmente porque é desprovido de consciência sentimental.

Para exemplificar como isso ocorreria na prática, observemos a jurisprudência a seguir elencada:

Recurso de Apelação - crime de estupro - art. 213 c/c art. 226, iii, do código penal - consentimento e comportamento da vítima - laudo pericial - negativa de autoria - provas. 1 . a vítima seguiu pacificamente o apelante para um lugar deserto, isto é, tinha desejo de ficar a sós com ele. 2. no decorrer da instrução processual, a vítima titubeou, ora dizendo ter sido estuprada, ora afirmando ter mantido relações sexuais com o apelante com seu consentimento - dúvida acerca da prática deli (...) (TJ-PA - APL: 200430003996 PA 2004300-03996, Relator: RAIMUNDA DO CARMO GOMES NORONHA, Data de Publicação: 04/05/2005).

Nota-se neste exemplo que, a suposta vítima, foi para um lugar onde poderia ficar a sós com o agente, não sendo possível, pelos relatos da mesma precisar se houve ou não o crime, mas,

seguindo a lógica difundida pela "cultura do estupro" o agente seria subjugado, ou seja, preteritamente, submetido à condenação socioideológica, pois, a palavra da vítima teria, como tem, valor maior em relação às demais provas.

Por fim, mas não menos importante, destaca-se que não há entendimento pacificado nos Tribunais Superiores a respeito desta circunstância judicial ao se tratar de crimes sexuais.

O que se teve até agora em relação a isso, foi uma ampla discussão sobre a vestimenta da vítima como influenciador da ocorrência do crime. Ressaltamos que 
consideramos esta assertiva irrelevante para a prática do crime, o que se trata aqui é efetivamente sobre o comportamento da vítima e não sobre o que ela veste.

Sendo assim, é extremamente importante, em situações como esta, que o julgador tenha o correto discernimento acerca dos conceitos de cada um dos elementos caracterizadores dos crimes contra a dignidade sexual, bem como a análise efetiva das circunstancias que permeiam o crime, para sopesar na fixação da pena, especificamente, da pena base, o benefício do "comportamento da vítima" em favor do agente.

Ademais, se demonstrará como sendo a "conditio sine qua non", para que condenações explicitamente equivocadas não se solidifiquem, de modo que atualmente, qualquer sujeito submetido ao procedimento investigativo e/ou judicial na apuração dos crimes contra a dignidade sexual, está subjugado à maior probabilidade de condenação que absolvição.

\section{PRINCÍPIOS APLICÁVEIS AO CRIME DE ESTUPRO}

Constatou-se no decorrer deste trabalho que, o julgador, na hipótese da prática de crime de estupro, especificamente, quando de sua instrução probatória, deverá primeiramente conhecer quais são seus elementos caracterizadores, para após, como consequência lógica, analisar o caso concreto e verificar a existência ou não da circunstância judicial prevista no art. 59 do Código Penal, qual seja, o comportamento da vítima.

Isso se deve, porque muitas vezes, mesmo que inconscientemente, é possível que a vítima contribua, senão, fomente esse desejo carnal insopitável, para que o sujeito pratique o crime. Pois bem, se ao julgador não incumbir essa árdua tarefa, especialmente no efetivo exame dos elementos constitutivos do tipo penal e não levar em consideração as circunstâncias que permearam sua decorrência, passível será a incidência de uma condenação equivocada, com expressiva violação de direitos e garantias fundamentais.

A Constituição Federal de 1988 instituiu um sistema que tem o principal objetivo de proteger os direitos e garantias individuais dos cidadãos brasileiros, isso fez com que se exigisse equilíbrio entre o dever de punir do Estado e a disposição das garantias individuais. Neste âmbito, o princípio da presunção da inocência foi instituído para que o poder punitivo do Estado não se demonstre absoluto, relativizando o trânsito em julgado da sentença penal condenatória, previsto na Constituição Federal em seu art. $5^{\circ}$, LVII, in verbis: “LVII - ninguém será considerado culpado até o trânsito em julgado de sentença penal condenatória". (BRASIL, Constituição Federal,1988).

Conforme Lima:

Em síntese, pode ser definido como o direito de não ser declarado culpado senão após o término do devido processo legal, durante o qual o acusado tenha se utilizado de todos os meios de prova pertinentes para a sua defesa (ampla defesa) e para a destruição da credibilidade das provas apresentadas pela acusação (contraditório). (LIMA, 2019, p. 45). 
Ressalta o autor, ainda, que deste princípio derivam duas regras "a regra probatória e a regra de tratamento", sendo que a primeira se relaciona efetivamente ao princípio do "in dubio pro reo".

A regra probatória é basicamente o pressuposto de que o órgão acusador deve solidificar a culpabilidade do acusado, ou seja, o ônus probatório lhe incumbe exclusivamente, não devendo restar dúvidas acerca da responsabilidade do agente, de modo que, deverá ser considerado inocente até o trânsito em julgado da sentença penal condenatória.

Acrescente-se, também, que acusação deve-se utilizar apenas de provas licitas e com o objetivo de demonstrar a responsabilidade do acusado, nas palavras de Lopes Junior (2020, p. 143): "Nessa perspectiva, acrescentamos a garantia de ser julgado com base em "prova" e não "meros atos de investigação" ou "elementos informativos" do inquérito".

Com relação à supracitada regra de tratamento, ainda, é de extrema relevância esclarecer que a prisão do agente fica condicionada ao esgotamento das vias recursais, conforme entendimento pacificado pelo STF, no julgamento das ADCs 43,44 e 54, de acordo com a notícia veiculada no site do próprio Tribunal (Notícias STF, 2019), pois em consonância com o princípio aqui tratado, o réu deverá responder ao processo em liberdade, ao passo que excepcional a restrição da sua liberdade.

Destaque-se que o princípio da presunção da inocência não se reveste de caráter absoluto, sendo que a prisão cautelar será passível, quando necessária, para garantir a efetividade do processo, nos termos dos arts.412 e 413, do Código de Processo Penal.

Ou seja, considerando-se que decorrente de Cláusula Pétrea (5, LVII, CF), em respeito ao princípio da presunção da inocência, o réu só será considerado e tratado como condenado (em decorrência de sentença penal), mediante o reconhecimento de provas efetivas da autoria e materialização ou participação do crime, bem como, só poderá ser preso antes do decreto condenatório para garantir a ordem pública, a ordem econômica, ainda, por conveniência da instrução criminal, ou para assegurar a aplicação da lei penal, quando houver prova da existência do crime e indício suficiente de autoria.

No que se refere ao princípio in dubio pro reo, este, é nas palavras de Lopes Junior (2020, p. 143 e 144):

[...] preceitos tradicionais da cultura jurídica, vinculados a valores humanitários de igualdade, respeito à dignidade da pessoa humana e liberdade, que devem ser os critérios axiológicos orientadores de toda e qualquer decisão judicial no âmbito criminal.

Destarte, o referido princípio, de acordo com Lima (2019, p. 46), “[...] deve ser utilizado no momento de valoração das provas: na dúvida, a decisão tem de favorecer o imputado, pois não tem ele a obrigação de provar que não praticou o delito".

Assim, sua importância está incutida na contextualização das dubiedades do julgador, pois, se prevalecentes, deverão ser compreendidas em favor do réu, isto 
é, quando não existem provas suficientes, ou seja, capazes de solidificar a culpabilidade do agente, ao passo que inversamente não lhe será imputado qualquer decreto condenatório.

Daí porquê, tanto o princípio da não culpabilidade quanto o princípio do in dubio pro reo são absorvidos pelo princípio do devido processo legal, expresso no art. $5^{\circ}$, LIV da Constituição Federal, que assegura: "ninguém será privado da liberdade ou de seus bens sem o devido processo legal". (BRASIL, Constituição Federal,1988).

Isso quer dizer que, preteritamente a qualquer interpretação garantista ou não, a todos deve-se dispor do exercício técnico da ampla defesa - na utilização, inclusive, de todos os meios legalmente admitidos -, e o contraditório - contrapondo-se livremente. Nas palavras de Távora e Alencar (2016, p. 65): “dentro de um procedimento regular, perante a autoridade competente, tendo por alicerce provas validamente colhidas, respeitando-se o contraditório de a ampla defesa".

Já o princípio da intervenção mínima é princípio excepcional que assegura os direitos e garantias fundamentais na intervenção mínima do Estado quando da restrição de direitos individuais.

Contextualmente, nas entrelinhas do controle social exercido pelo Estado, ao Direito Penal, deve-se reservar apenas o imprescindível. O princípio da intervenção mínima, portanto, relaciona-se, com o entono penal do bem jurídico (tutelado). Outrossim, o Direito Penal só deve ser utilizado quando extremamente necessário, pois, subsidiário e fragmentário.

Observe-se, consequentemente, que se outras formas de sanção ou meios de controle social $r$

evelarem-se suficientes para a tutela desse bem jurídico ameaçado, qualquer criminalização demonstrar-se-á inadequada e não recomendável. Em outras palavras, se o restabelecimento da ordem jurídica (ameaçada ou violada) demonstrar suficiente, tais como - sem qualquer pretensão de esgotamento da matéria -, medidas civis ou administrativas, serão estas prioritárias, subsidiando o Direito Penal.

No caso do estupro, temática central do presente trabalho, por se tratar de conduta hedionda e, portanto, de extrema gravidade (inclusive, abstrata) exige-se a tutela do Direito Penal.

Neste sentido, Ponte leciona:

Segundo o princípio da intervenção mínima, o direito penal deve ter caráter subsidiário, devendo atuar como a última ratio legis, depois que todos os outros ramos do Direito tenham se mostrado inócuos e incapazes de salvaguardar bens jurídicos-penais relevantes. [...] Sustentada a aplicação do princípio da intervenção mínima, forçoso reconhecer que as contravenções penais não podem permanecer incólumes. Ora, se determinados bens ou interesses não assumem relevância suficientes para que suas violações caracterizam crime, como justificar suas respectivas permanências no ordenamento jurídico quando, sabidamente, outros ramos do Direito cuidariam da aludida tarefa? (PONTE, 2008, p. 74-75). 
Conclui-se desse princípio, portanto, o importante papel do Direito Penal, na proteção e garantia dos direitos fundamentais da coletividade.

O Princípio da Proporcionalidade é de grande importância no Direito Penal, apesar de não estar positivado na Constituição Federal. Destarte, para a presente temática é um dos princípios mais importantes, senão, o de maior relevância. Isto, pois, conforme extensamente discorrido, demonstra-se substancial a dificuldade de correta interpretação para devida caracterização do crime de estupro, trazendo à tona que apesar dos esforços do legislador na criação de tipos penais específicos, como o da importunação sexual, a figura do estupro se sobrepõe, seja por ausência de conhecimento técnico da sociedade e/ou de informação. Consequentemente, evidencia- se o julgamento antecipado do agente - rotulado como estuprador, com probabilidade de condenação absoluta.

Não obstante, repise-se, é de extrema importância que o magistrado avalie todas as condições e circunstâncias que permearam o crime. Justamente nessas entrelinhas, deverá incidir o princípio da proporcionalidade.

Nas palavras de Távora e Alencar (2016, p. 73), "o princípio da proporcionalidade, de origem germânica representa um procedimento de aplicação/interpretação de norma jurídica tendente a concretizar um direito fundamental em dado caso concreto".

Ou seja, o princípio da proporcionalidade, no âmbito da dosimetria da pena, irá sopesar a ação, ou o crime (caso concreto) e a pena que deverá ser aplicada.

Admite-se na doutrina atual que este princípio seja tratado como "superprincípio" pois, deve- se sopear na hipótese de conflito com outros princípios, além de reconhecido como limitador da atividade estatal, "já que os fins da persecução penal nem sempre justificam os meios, vedando-se a atuação abusiva do Estado ao encampar a bandeira do combate ao crime". (TAVORA; ALENCAR, 2016, p. 74).

O princípio da proporcionalidade tem especial aplicação no direito processual penal, tal como se dá na disciplina legal da validade da prova. Se a utilização do princípio da proporcionalidade em favor do réu para o acatamento de prova que seria ilícita é pacifica, essa mesma utilização contra o réu para o fim de garantir valores como o da segurança coletiva é bastante controvertida no Brasil. Pode-se dizer que é minoritário o setor da doutrina e da jurisprudência que defende a aplicação excepcional do princípio da proporcionalidade contra o acusado, para satisfazer pretensões do "movimento da lei e da ordem". (TAVORA; ALENCAR, 2016, p. 74).

Dessa forma, em uma possível, senão, provável condenação pelo crime de estupro, o princípio da proporcionalidade terá de ser aplicado na primeira fase da dosimetria da pena, levando-se em consideração o comportamento da vítima de modo que reflita na redução da pena do acusado ${ }^{6}$.

6 Suponhamos que o acusado esteja dando uns amassos calorosos na suposta vítima e que parta para o início da relação sexual. Durante o ato a suposta vítima exprima o desejo de descontinuar o ato, mas o agente não para, pois no calor do momento não achou que a suposta vítima estava falando sério e daí seja acusado deestupro. 
Uma vez esclarecidos os conceitos básicos acerca dos supramencionados princípios, se faz necessário aplicá-los efetivamente ao tema do nosso trabalho.

Constata-se cotidianamente, que simples ações de cunho sexual, socialmente, descritas e interpretadas como estupro, não se enquadram nesta definição (legal), ocasionando condenações desproporcionais.

A condenação injusta, por sua vez, nos remete à aplicação dos princípios penais, base para que o Poder Judiciário exerça seu "poder" corretamente.

Destarte, o reconhecimento do estupro (art. 213, CP) em detrimento da importunação sexual (art. 215, CP), solidifica a violação do princípio da proporcionalidade, pois, a pena aplicada ao primeiro é sobremaneira maior do que a pena aplicada ao segundo.

Compreenda-se, igualmente, quando a suposta vítima contribui para a consumação do crime, de forma que, por exemplo, seduza o agente para depois acusá-lo. Destaque-se que, prioritariamente, a acusação - independentemente de conhecimento técnico -, será de estupro.

Observe-se, não se leva, naturalmente, às elementares constitutivas que determinam o respectivo crime, pelo que, consequentemente, estar-se-á diante da violação dos princípios da não culpabilidade e in dubio pro reo.

Sublinhe-se, aliás, a determinante valoração da palavra da (suposta) vítima que nos crimes de natureza sexual, por questões de cultura ou não, se sobrepõe à palavra do acusado. Em razão de tal, considerando-se unicamente a palavra da vítima, alternativa não haverá, senão sua condenação.

Em relação aos princípios da intervenção mínima e da lesividade, constata-se que o Direito Penal tem um papel de suma relevância para a garantia da liberdade sexual.

Porém, especificamente quanto ao princípio da lesividade, necessário se faz observar que, nos crimes cujos elementos constitutivos não se correlacionem com o estupro, assim deverão ser reconhecidos (respectivamente). Conjecture-se que a prática de quaisquer atos importunos (art. 215, CP), obviamente de caráter sexual, não se confundem com atos libidinosos ou conjunção carnal e, para tanto, não devem constituir o crime de estupro.

É, exatamente a delimitação do grau de lesividade, sob pena de condenações equivocadas e, sobretudo, subversivas.

\section{CONSEQUENNCIAS DE UMA CONDENAÇÃO INJUSTA}

Salta aos olhos a quantidade de pessoas que são presas injustamente pelo crime de estupro; uma pesquisa rápida na internet revela inúmeras reportagens que tratam do assunto, descrevendo diversos casos.

Como já aludido extensivamente durante este trabalho, essas condenações foram baseadas quase que exclusivamente na palavra da suposta vítima, o que corrobora com nossa tese.

Dessa forma, para a conclusão deste trabalho é imprescindível fazermos a análise de alguns desses casos, conhecendo as histórias e os motivos que levaram essas pessoas a serem acusadas e presas injustamente pelo crime de estupro. 
Antônio Carlos Barbosa, que teve seu caso patrocinado pela ONG INNOCENCE PROJECT BRASIL, segundo artigo publicado no site JusBrasil (2019, p. [1]) foi condenado e preso pelo estupro de oito mulheres no ano de 2014. Acrescente-se, preso no lugar do verdadeiro criminoso, conhecido como "Maníaco da moto".

\begin{abstract}
A advogada Flávia Rahal afirma também que "a única coisa que sustentou a condenação foi o reconhecimento feito pela vítima" - não houve exame de DNA, por exemplo. O reconhecimento foi feito por uma criança de 11 anos, vítima de estupro. Conforme Rahal, a criança se equivocou ao se convencer de que o borracheiro foi o autor do crime (JUSBRASIL, 2019, p. [2]).
\end{abstract}

Ainda segundo o artigo (JusBrasil, 2019, p [2]), a defesa de Antônio conseguiu provar sua inocência provando que sua altura era diferente da do verdadeiro criminoso, bem como, que não possuía o veículo que era utilizado pelo mesmo para abordar as vítimas.

Um segundo caso, ocorreu com o artista plástico Eugênio Fiuza de Queiroz, que ficou preso durante 18 anos, acusado de cinco estupros, enquanto o verdadeiro criminoso, conhecido como "Maníaco da Anchieta", ficou solto.

Segundo Próton (2019, p. 2), Eugênio foi preso enquanto conversava com sua namorada, sem mandado de prisão, apenas com o reconhecimento de uma das vítimas e inocentado após o reconhecimento de uma das vítimas, do verdadeiro criminoso.

Podemos notar nesses casos que ambos foram condenados, com base (unicamente) nas palavras das vítimas. Os casos aqui demonstrados têm o condão de comprovar a expressividade da problemática.

Analisando essas situações é trivial questionar suas razões. A má-fé, por exemplo, de algumas mulheres em acusar falsamente um homem de violentá-la - escarnecendo de um crime tão horrendo, impulsionando a máquina jurídica injustificadamente, demonstra-se, incidente.

Além disso, denota-se também nos casos de crimes sexuais, a incidência de um fenômeno descrito na psicologia jurídica como Síndrome da Falsa Memória, a síndrome da falsa memoria, consiste em:

(...) memórias fabricadas ou forjadas, no todo ou em parte, na qual ocorrem relatos de fatos inverídicos, supostamente esquecidos por muito tempo e posteriormente relembrados. São erros que se devem à memória, e não à intenção de mentir. Podem ser implantadas por sugestão e consideradas verdadeiras e, dessa forma, influenciar o comportamento. (TRINDADE,2012, p.221).

Em suma, tal síndrome faz com que a pessoa acredite que um fato ocorreu, quando na verdade não ocorreu. No campo penal, esse fenômeno é extremamente importante. Trindade nos explica porque: 
A recuperação de memórias recalcadas tem sido fonte de muita controvérsia no âmbito da psicologia jurídica quanto do direito, pois a memória é uma função sujeita a distorções e falsificações, erros e imprecisões. Por esse motivo, em matéria penal não se pode aceitar a condenação baseada única e exclusivamente nesse tipo de prova. Forjada por equívoco da própria vítima ou implantada por terceiro, trata-se de falsa memória. (TRINDADE, 2012, p. 222).

Aplicando diretamente ao assunto tratado na presente pesquisa, especificamente na valoração da palavra da vítima, denota-se que muitas vezes quando se trata da identificação do criminoso, essas vítimas podem reconhecer uma pessoa como seu agressor em detrimento de outra.

O intuito na descrição das informações acerca deste fenômeno, se resume única e exclusivamente em demonstrar sua naturalidade atual, ou seja, mais comum do que se imagina, principalmente no âmbito dos crimes sexuais.

Ora, em todos os exemplos de condenações injustas trazidos neste capítulo é de se notar que as supostas vítimas, se confundiram ou mentiram a respeito ao agressor.

Na jurisprudência elencada abaixo notamos que quando a palavra da vítima se demonstrar inconsistente, não se pode sobrepô-la a outras provas existentes:

RECURSO DE APELAÇÃO CRIMINA- CRIME CONTRA A DIGNIDADE SEXUAL E PORTE ILEGAL DE ARMA DE FOGO SENTENÇA ABSOLUTÓRIA - IRRESIGNAÇÃO DO MINISTÉRIO PÚBLICO - PEDIDO DE CONDENAÇÃO COM RELEVÂNCIA NOS DEPOIMENTOS DAS VÍTIMAS - INSUFICIÊNCIA DE PROVAS - PALAVRAS DAS VÍTIMAS INCOERENTES E CONTRADITÓRIAS, DISSOCIADAS DOS DEMAIS ELEMENTOS PROBATÓRIOS COLHIDOS - APLICAÇÃO DO PRINCÍPIO IN DUBIO PRO REO - DECISÃO ESCORREITA - DESPROVIMENTO DO RECURSO. Deve ser mantida a sentença absolutória das imputações da prática de crimes contra a dignidade sexual quando, além da inexistência de testemunhas presenciais, não se puder sobrevelar as palavras das vítimas, tendo em conta as inúmeras incoerências nelas constatadas, reforçadas pela ausência de harmonia com os demais elementos probatórios, devendo prevalecer o príncipio do in dúbio pro reo. (N.U 0021516-84.2009.8.11.0000, LUIZ FERREIRA DA SILVA, TERCEIRA CÂMARA CRIMINAL, Julgado em 05/05/2010.

Dessa forma, corroborando com nossa tese, concluímos que, seja pela chamada "cultura do estupro", má-fé, síndrome das falsas memórias ou qualquer outra razão, o pré-julgamento prevalecerá em detrimento da ciência jurídica.

A contrario sensu, na hipótese de cooperação da vítima, a pena, deverá, acertadamente, ser relativizada.

Nesse contexto, voltamos ao tema principal deste capítulo, qual seja as consequências que essas condenações trouxeram para as vidas desses homens inocentes.

Antônio Carlos em entrevista para o site Metrópoles relata: 
Ainda é uma grande luta, um grande sofrimento, porque era para eu estar livre, mas eu não me sinto livre. Meu nome ainda consta no sistema. Quando eu saio, tenho receio. Já sofri dois constrangimentos por causa do meu nome no Sistema. Para mim, é muito difícil", disse o borracheiro ao portal. Ele destacou que ainda teme ser encarcerado novamente a cada abordagem da polícia. (METROPOLES, 2019, p. [4]).

No caso de Eugênio, as consequências foram piores, de acordo com Próton:

Segundo a Justiça, o artista plástico alegou ainda que confessou os crimes mediante tortura física e psicológica. $\mathrm{Na}$ ação, ele citou ainda que, durante o período em que esteve preso, perdeu o contato com a família, em especial com o filho. Só depois de sair da prisão, ele descobriu que a mãe dele e cinco irmãos haviam morrido" (G1, 2019, apud Próton 2019, p. [2]).

Esses dois casos foram bastante emblemáticos, e as suas narrativas apenas servem para demonstrar uma parte das consequências que uma condenação pelo crime de estupro pode trazer.

Além das consequências psicológicas, como demostrado nos casos supramencionados, existe uma ainda mais séria, o estupro carcerário.

"Quem entra no presídio por estupro deve ser estuprado" (MARQUES JÚNIOR, 2007, p. 178), esse é um fato conhecido socialmente, ao estuprador que vai para a cadeia, é feita a "Justiça com as próprias mãos".

[...] independente de ser condenado pelo crime, "na carceragem o estuprador já sofre", e se for colocado em contato com outros presos também corre risco de vida. Esta violência não se restringe ao atentado violento ao pudor, mas é acompanhada de agressões, humilhações, castigos e torturas, podendo chegar à morte. (MARQUES JUNIOR, 2007, p. 102)

Ao que nos parece, isso não chegou a ocorrer nos casos aqui retratados, mas sim, é uma realidade do nosso sistema carcerário, ao passo que as consequências de uma condenação equivocada serão terríveis.

Mas, quais as consequências, que deveriam ser aplicadas para aqueles que acusam falsamente alguém de cometer determinado crime?

A mais comum é o enquadramento no crime de denunciação caluniosa, previsto no art. 339 do Código Penal, in verbis:

Art. 339. Dar causa à instauração de investigação policial, de processo judicial, instauração de investigação administrativa, inquérito civil ou ação de improbidade administrativa contra alguém, imputando-lhe crime de que o sabe inocente...". (BRASIL, Código Penal, 1942).

Também é possível que o condenado injustamente receba indenização pelo Estado, conforme previsto no art. 630 do Código de Processo penal: “Art. 630. O tribunal, se o interessado o requerer, poderá reconhecer o direito a uma justa indenização pelos prejuízos sofridos...". (BRASIL, Código de Processo Penal, 1941). 
Destaque-se, contudo, que absolutamente nenhum instituto restabelecerá as consequências suportadas, além do tempo perdido. Ainda, porque, as penas entre denunciação caluniosa e estrupo, além do caráter social, minimamente se equivalem.

\section{CONCLUSÕES FINAIS}

A conclusão do presente artigo é que como de praxe tende-se erroneamente a justificar os mais diversos assuntos baseando-se em ideologias e o aumento no número de casos de estupro não é diferente.

Assim, justifica-se tal aumento a partir do movimento feminista que prega a existência de um machismo enraizado em todos os homens que consequentemente têm atitudes que facilitam o cometimento de crimes sexuais (cultura do estupro). Dessa forma, tende-se a atribuir ao estupro qualquer ato sexual considerado violador, e o resultado disso é uma condenação social e até mesmo judicial injusta por crime que muitas vezes nem ao menos foi cometido.

É claro que deve sempre haver o respeito - e acreditamos que a ideia principal de difundir a existência de uma cultura do estupro, apoiada pelo movimento feminista, é essa; porém, ela se demonstra incapaz de promover isto. Contrariamente prega a desinformação, tornando a mulher indefesa e ignorante, fazendo com que ao invés de procurar as autoridades competentes ao ser vítima de uma violação, recorra cegamente aos apoiadores dessa cultura, escrevendo textos enormes nas redes sociais, que nada resolvem, ignorando completamente o fato de que o estuprador não estupra porque é machista, e sim porque é mau.

Dessa forma, na seção 1 deste artigo foi necessário revermos os conceitos de cada um dos crimes sexuais previstos no Capítulo VI, Título I do Código Penal. E a conclusão que podemos tirar desta é que cada tipificação tem sua particularidade, sendo complementarmente possível diferenciá-las. Dessa forma, é necessária análise profunda de cada caso de violação sexual, para que haja o enquadramento correto no tipo penal correspondente, evitando-se condenações desnecessárias.

Na seção 2 adentramos no conceito específico de cultura de estupro e vitimologia e a relação entre os dois de como por influência desta cultura tende-se a denominar os atos considerados violadores como estupro.

Destarte, o objetivo nunca foi de justificar a prática de tal conduta, e sim de esclarecer que nem sempre ocorre o crime sexual, e que caso efetivamente ele ocorra que o agente seja devidamente punido, mas punir alguém por qualquer ato, quando este é atípico, é nefasto.

O que essa cultura deveria pregar é o conhecimento - conhecimento para fazer as mulheres mais fortes e não construir mulheres covardes que precisam fazer esse tipo de acusação apenas para se sentirem mais mulheres, além do fato de que, conforme já mencionado, existe uma grande diferença entre um estuprador, que sai de casa realmente para estuprar, e um tolo. Além disso, quando por intermédio dessa cultura valoriza-se mais a palavra da mulher como vítima acima de outras provas e disso decorre uma condenação injusta, ela é inconstitucional pois viola vários princípios, conforme visto na seção 3 . 
Por fim, cabe ressaltar que aquele tachado como estuprador suporta consequências destrutivas, pois, nas penitenciárias tem-se um rígido código de conduta a ser seguido e o estuprador ou é estuprado ou morre.

Resta claro, portanto ser necessário adotar outra forma de julgamento dos crimes sexuais, não levando em consideração ideologias, valorando igualmente todas as provas, tendo o efetivo conhecimento do crime e das circunstâncias que o permearam, evitando que inocentes se submetam ao cárcere, comprometendo, inclusive sua vida.

\section{REFERENNCIAS}

13º Manual de Segurança Pública. Disponível em: <http://www.forumseguranca.org. $\mathrm{br} /$ publicacoes/13-anuario-brasileiro-de-seguranca-publica/>. Acesso em: 08 de março de 2020 .

BITENCOURT, CEZAR ROBERTO. Anatomia do crime de importunação sexual tipificado na Lei 13.718/2018. Conjur, 2018. Disponível em <https://www.conjur.com.br/ 2018-set-30/cezar-bitencourt-anatomia-crime-importunacao-sexual $>$ Acesso em: 8 de março de 2019.

BRASIL. DECRETO No 2.848, DE 7 de dezembro de 1940. Disponível em: <http:/ /www. planalto.gov.br/ccivil_03/decreto-lei/del2848compilado.htm >. Acesso em: 08 de março de 2020.

BRASIL. DECRETO-LEI No 3.689, DE 3 DE OUTUBRO DE 1941. Disponível em <http:/ / www.planalto.gov.br/ccivil_03/decreto-lei/del3689compilado.htm>. Acesso em: 18 de maio de 2020.

BRASIL. DECRETO-LEI No 10.224, DE 15 DE MAIO DE 2001. Disponível em < http:// www.planalto.gov.br/ccivil_03/leis/leis_2001/L10224.htm>. Acesso em: 18 de maio de 2020.

BRASIL. DECRETO-LEI No 12.015, DE 7 DE AGOSTO DE 2009. Disponível em < http:/ / www.planalto.gov.br/ccivil_03/_ato2007-2010/2009/lei/112015.htm>. Acesso em: 18 de maio de 2020.

BRASIL. DECRETO-LEI No 13.718, DE 24 DE SETEMBRO DE 2018. Disponível em < http://www.planalto.gov.br/ccivil_03/_ato2015-2018/2018/lei/L13718.htm>. Acesso em: 18 de maio de 2020.

BRASIL. Constituição da República Federativa do Brasil de 1998. Disponível em:< http://www.planalto.gov.br/ccivil_03/constituicao/constituicao.htm>. Acesso em 05 de maio de 2020.

BRASIL. Tribunal de Justiça do Mato Grosso. N.U 0021516-84.2009.8.11.0000, Relator: LUIZ FERREIRA DA SILVA. MT 05/05/2010. JUSBRASIL, 2010. Disponível em: < https://tj-mt.jusbrasil.com.br/jurisprudencia/328175047/apelacao-apl-215168420098110000-21516-2009/relatorio-328175104> Acesso em 18 de maio de 2020.

BRASIL. Tribunal de Justiça do Pará. APELAÇÃO No: 200430003996 PA 200430003996. Relator: RAIMUNDA DO CARMO GOMES NORONHA, PA: 04/05/2005. 
Disponível em: <https://tj-pa.jusbrasil.com.br/jurisprudencia/5570641/apelacao-penal-apl-200430003996-pa-2004300-03996-tjpa?ref=serp >. Acesso em: 29 de abril de 2020.

BRASIL Tribunal de Justiça do Rio Grande do Sul. Apelação Crime, No 70041208786, Relator: Cláudio Baldino Maciel. RS: 30-06-2011. Disponível em <https://www1.tjrs.jus. br/site_php/consulta/consulta_processo.php?nome_comarca=Tribunal $\% 20 \mathrm{de} \% 20 \mathrm{Jus}$ ti $\%$ C3\% A7a \%20do\%20RS\&versao=\&versao_fonetica=1\&tipo=1\&id_comarca=700\&num processo_mask=\&num_processo $=70041208786 \&$ codEmenta $=7706337 \&$ temIntTeor $=$ true $>$ Acesso em 18 de maio de 2020.

Caso Neymar: Polícia de SP indicia Najila por extorsão, fraude processual e denúncia caluniosa. G1, 2019. Disponível em: <https://g1.globo.com/sp/sao-paulo/noticia/2019/09/10/policia-de-sp-indicia-najila-e-ex-marido-por-extorsao-fraude-processual-e-denuncia-caluniosa-no-caso-neymar.ghtml > Acesso em: 28 de abril de 2020.

CERQUEIRA, D.; COELHO, D. S. C. Estupro no Brasil: uma radiografia segundo os dados da Saúde. Brasília: Ipea, 2014. (Nota Técnica, n. 11).

Condenado por estupro é inocentado em novo julgamento após cinco anos preso por engano. Jusbrasil, 2019. Disponível em< https://doutoradevogado.jusbrasil.com.br/noticias/738737838/condenado-por-estupro-e-inocentado-em-novo-julgamento-apos-cinco-anos-preso-por-engano> Acesso em: 15 de maio de 2020

ESTEFAM, André. Direito penal, volume 2: parte especial. 5 ed. São Paulo: Saraiva Educação, 2018.

FILHO, Nestor Sampaio Penteado. Manual Esquemático de Criminologia. 9 ed. São Paulo: SaraivaJur, 2019.

GUIA MUNDO EM FOCO: cultura do estupro. São Paulo: On Line, 2016. Disponível em: <https:/ / tinyurl.com/y8yvodor>Acesso em 15 de maio de 2020.

GRECO, Rogério. Código Penal Comentado. 11 ed. Rio de Janeiro: Impetus, 2017.

Homem que ficou 5 anos preso injustamente: "Não me sinto livre". Metrópoles, 2019. Disponível em <https://www.metropoles.com/brasil/homem-que-ficou-5-anos-preso-injustamente-nao-me-sinto-livre> Acesso em: 15 de maio de 2020

JESUS, Damásio de. Direito penal: Parte Especial. 21 ed. São Paulo: Saraiva, 2013.

LIMA, Renato Brasileiro de. Manual de processo penal: volume único. 7 ed. Salvador: JusPodivm, 2019.

LOPES JUNIOR, Aury . Direito Processual Penal. 17 ed. São Paulo: Saraiva, 2020.

MARCÃO, Renato; GENTIL, Plínio. Crimes Contra a Dignidade Sexual: Comentários ao Título VI do Código Penal. São Paulo: Saraiva: Educação, 2018.

MARQUES JUNIOR, Gessé. “Quem entra com estupro é estuprado": avaliações e representações de juízes e promotores frente à violência no cárcere. 2007. 188f. Dissertação (Mes- 
trado em Direito) - Programa de Pós-Graduação em Direito - Universidade Metodista de Piracicaba, Piracicaba, 2007. Disponível em: <http:/ / observatoriodeseguranca.org/files/ cp037977.pdf>Acesso em: 18 mai. 2020.

NUCCI, Guilherme de Souza. Curso de direito parte especial: arts. 213 a 361 do código penal. 3 ed. Rio de Janeiro: Forense, 2019

NUCCI, Guilherme de Souza. Crimes Contra a Dignidade Sexual. Rio de Janeiro: Forense, 2014.

PALOMBA, Guido Arthuro. Perícia na Psiquiatria Forense. São Paulo: Saraiva, 2016.

PONTE, Antonio Carlos da. Crimes Eleitorais. São Paulo: Saraiva, 2008.

PRÓTON, Sara. Fábrica de Queiroz: 18 anos preso por estupros que não cometeu em BH. Jusbrasil, 2019. Disponível em <https:/ / saraproton.jusbrasil.com.br/noticias/768452053/ fabrica-de-queiroz-18-anos-preso-por-estupros-que-nao-cometeu-em-bh> Acesso em: 15 de maio de 2020.

REIS, Alexandre Cebrian Araújo; GONÇALVES Victor Eduardo Rios. Direito processual penal esquematizado. 6 ed. São Paulo: Saraiva, 2017.

SALIM, Alexandre e AZEVEDO, Marcelo André. Direito Penal - Parte Especial - Dos crimes contra a pessoa aos crimes contra a família. 5 ed. Salvador: Juspodivm, 2017.

SANCHES, Rogério. Manual de Direito Penal - Parte Especial. 9 ed. Salvador: Juspodivm, 2017.

SOUZA, Artur de Brito Gueiros e JAPIASSÚ, Carlos Eduardo Adriano. Direito penal: volume único. São Paulo: Atlas, 2018.

STF decide que cumprimento da pena deve começar após esgotamento de recursos. STF, 2019. Disponível em <http:/ / www.stf.jus.br/portal/cms/verNoticiaDetalhe.asp?idConteudo=429359> Acesso em: 18 de maio de 2020 .

TAVORA, Nestor; ALENCAR, Rosmar Rodrigues. Curso de Direito Processual Penal. 11 ed. Salvador: Juspodivm: 2016.

TRINDADE, Jorge. Manual de Psicologia Jurídica para operadores do Direito. 6 ed. Porto Alegre: Livraria do Advogado Editora, 2012. 